\title{
The determined painter: Sir Frederick Banting
}

Previously published at www.cmaj.ca

Science and art were Sir Frederick Grant Banting's (1891-1941) “undiscover'd country" "that he determinedly explored throughout his life.

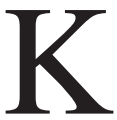
nown to the world as the codiscoverer of insulin and corecipient of the 1923 Nobel Prize in Medicine, Banting's diligent observational skills as well as his penchant for detail and note taking, as both scientist and physician, were applied to a variety of artistic pursuits. He had hoped to pursue art full time after his 50th birthday, but died in an airplane crash in Newfoundland at the age of 49. What remains of Banting's artistic efforts is a legacy of hundreds of paintings and sketches of wilderness scenes, rural and town landscapes and the human form. They demonstrate Banting's capacity for intense observation and his desire to improve his skills as an artist even under harsh conditions.

In 1923, Banting stated that "If a man thinks hard enough he can accomplish any rational task." ${ }^{2}$ Banting's achievements in science, and in art, were founded on hard work and the belief that he could overcome obstacles. In the case of art, the obstacles included learning the necessary skills.

Banting's early exposure to art came from the illustrated books in the family's library, including The Pilgrim's Progress, Dickens' novels, and Conan Doyle's Sherlock Holmes series. As a youth he became interested in pyrography, the art of burning images into wood. His great nephew, Bob Banting reports that his uncle made objects from wood throughout his life and was constantly whittling, as well as sketching. Banting began painting watercolours in 1920 to pass the time while waiting for patients. After his scientific success, painting became an escape

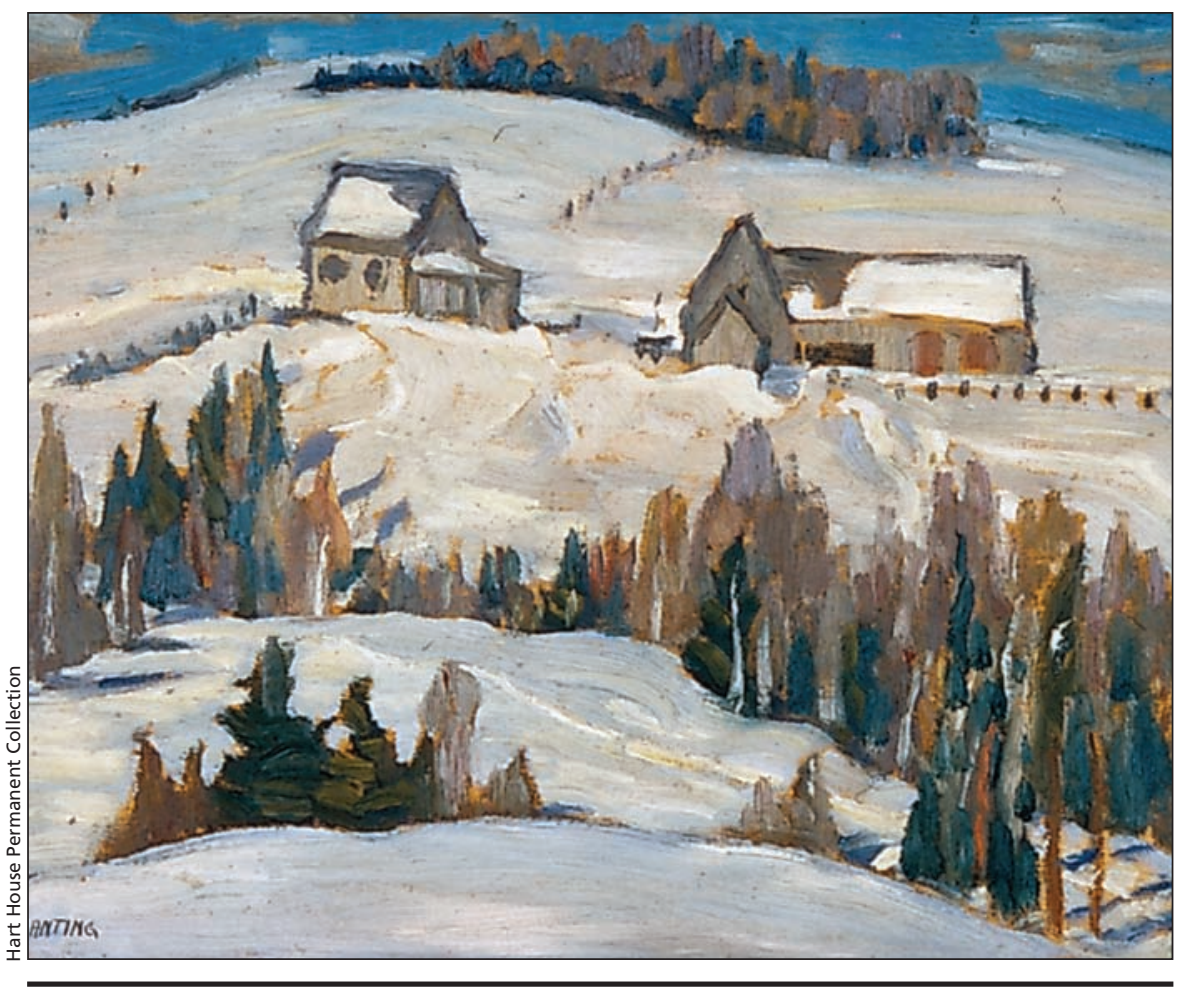

Frederick Banting, French Countryside, 1937. Oil on canvas. $22 \times 26 \mathrm{~cm}$. Hart House Permanent Collection, University of Toronto. Donated by Lady Henrietta Banting, 1954. 1954.01

from the fame and attention that the reticent Banting disliked so intensely.

In 1925, he joined the Arts \& Letters Club in Toronto, Ont., where he became friends with the Group of Seven's founding member and one of Canada's leading landscape artists, A.Y. Jackson. The two had much in common: they both served on the Western Front during World War I and shared a love for the outdoors and landscape painting. Over the next 16 years, the men enjoyed many painting excursions, some lasting as long as two months, beginning with a trip to rural Quebec in March 1927 and including a memorable trip to the Eastern Arctic. They painted and sketched en plein air, lived in the rough and explored the wilderness. In, A Painter's Country: The Autobiography of A.Y. Jackson,
Jackson recalls one time when the snow drifted into Banting's sketch box and Banting's hands were so cold he could barely paint. Banting reportedly said to Jackson, "And I thought this was a sissy game."

Banting was always determined to improve his work and would show Jackson his sketches asking, "Now, what's wrong with it?" In a sketch book from a trip to the Rocky Mountains in 1928 he wrote that: "One gets out of life what one puts into it. It is the same with science or the branches of art."

Certainly, Banting invested a lot of time and effort into learning to sketch and paint, and in his lifetime he became one of Canada's best known amateur artists. During the Rocky Mountain trip, his detailed sketches display confidence in the bold strokes in charcoal pencil 


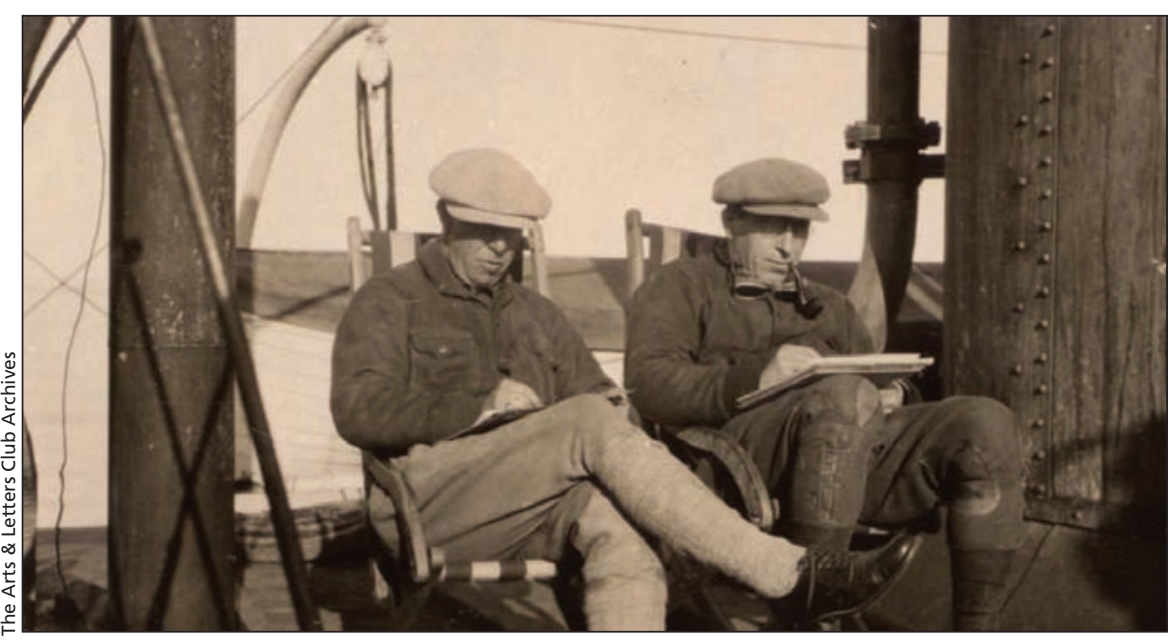

This picture of A.Y. Jackson (left) and Banting was taken aboard the Beothic on a 1927 trip to Ellesmere Island.

and meticulous attention to detail in his totem poles and the peculiarities of faces. In 1933, Banting's sketches in Spain show a maturing skill.

Banting, the scientist was oft times evident in his work. For example, the Spanish pencil and ink sketches have detailed notations about the place, day, hour and minute the work was created. Another sketch includes notes about birds, cells and fibroblasts. A 1908 sketch book features a landscape with a detailed grid charting the barometric fluctuations for the date Mar. 30, 1908. A few of Banting's Rocky Mountain sketches had notes on colour and shading, however, many of the Spanish land-, farm- and townscapes evoke a paint-by-numbers kit, as Banting, thinking like a painter and scientist, dissected his sketched scenes into blocks of colour and shading. One sketch of an old castle $(10.8 \times 17.5 \mathrm{~cm})$, done on Nov. 14, 1933 at 3 pm, is detailed with notes like "blue shadows," "3 cream to yellow ochre" and "towers red brown."

Years of seeing internal landscapes through a microscope and looking for specific elements in a slide, may also have taught Banting how to frame a scene and focus on important elements for a composition. In his Spanish townscapes and Canadian city and farm scenes he used a $4 \times 4$ inch grid to ensure the correct perspective, horizon

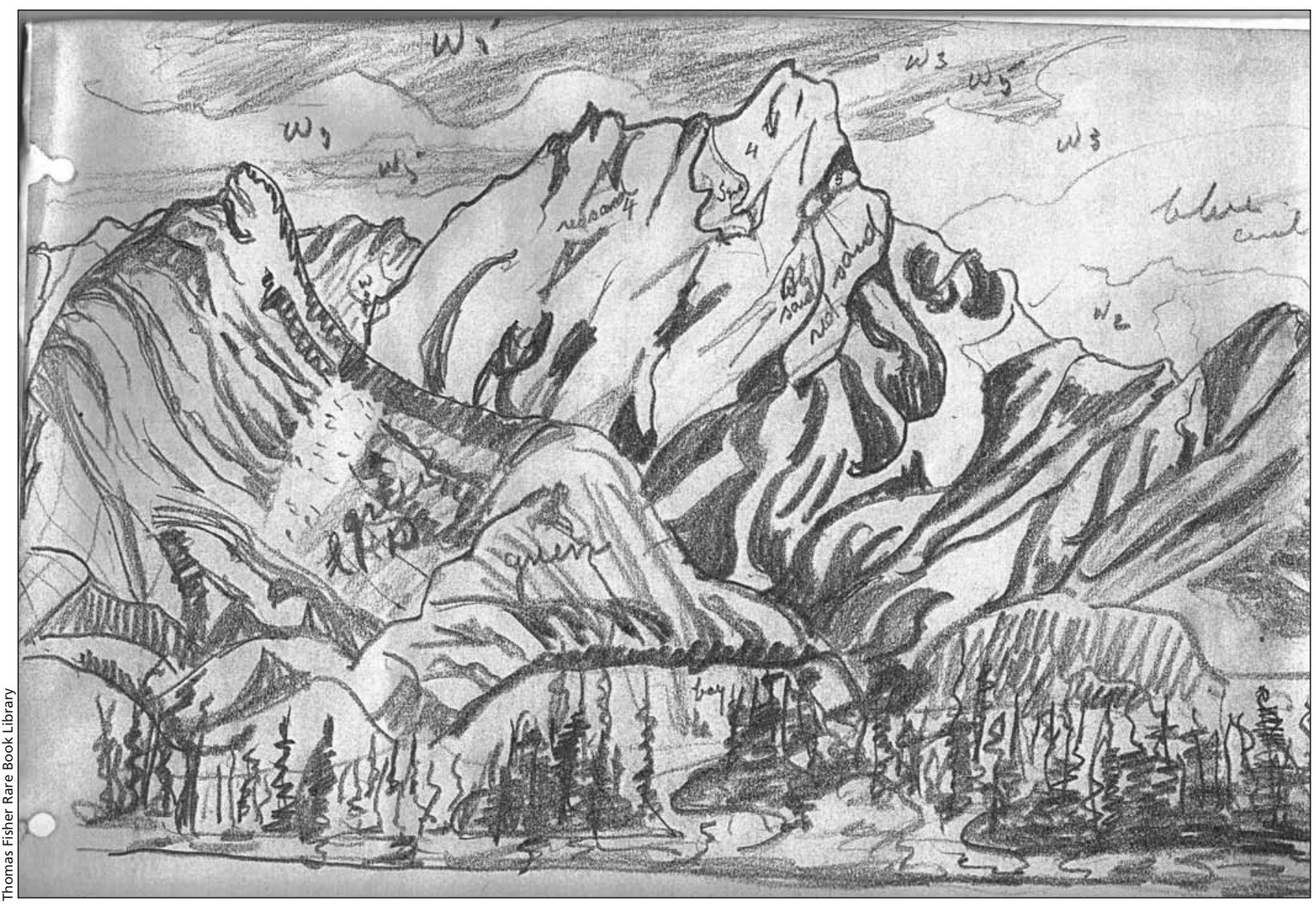

This sketch from Banting's trip to the Rocky Mountains in 1928 shows the influence of A.Y. Jackson. (Thomas Fisher Rare Book Library, University of Toronto, MS COLL 76, Box 43B; Rocky Mountain sketch book, p. 4.) 


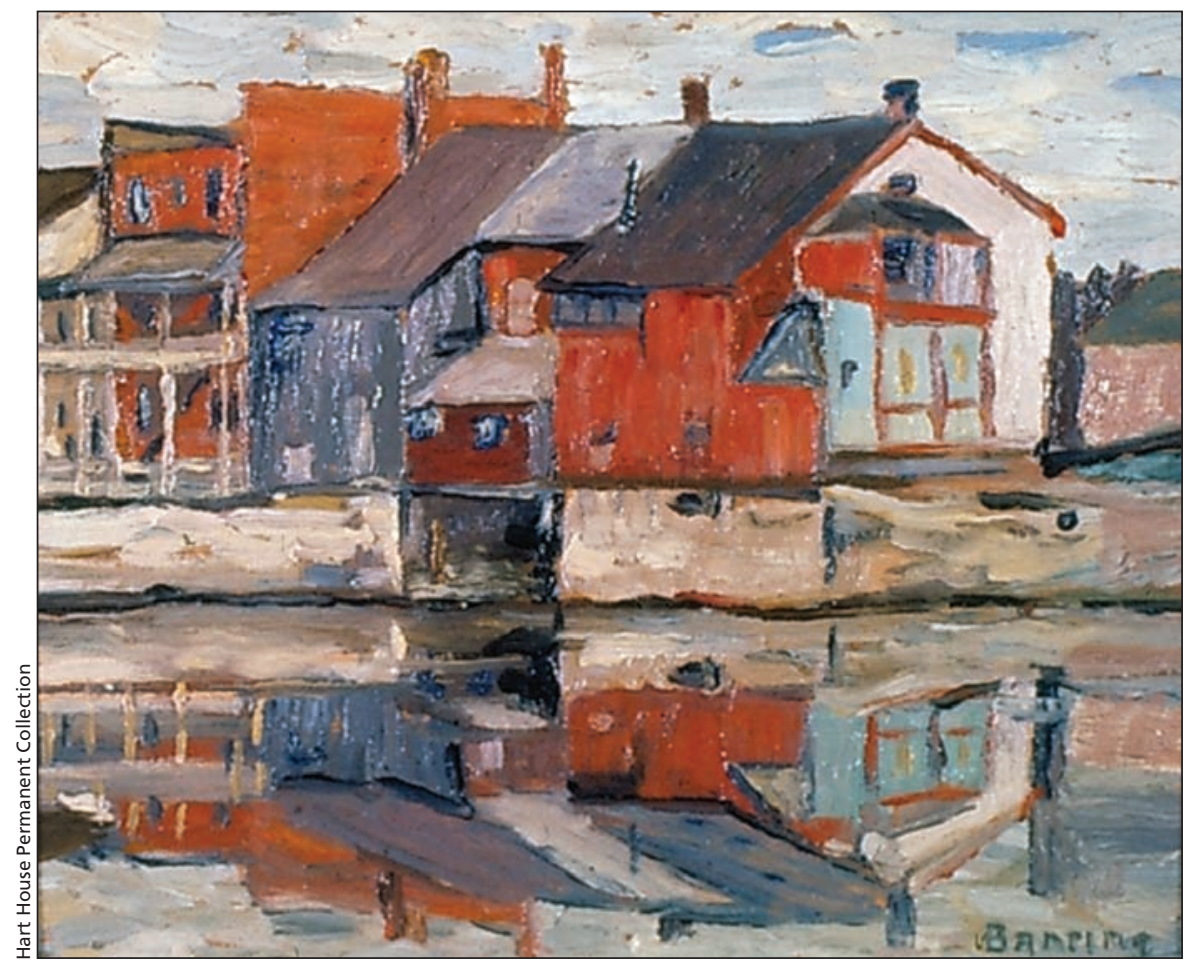

Frederick Banting, Elora, 1927. Oil on panel, $22 \times 27 \mathrm{~cm}$. Hart House Permanent Collection, University of Toronto. Donated by A.Y. Jackson, 1962. 1962.02 line and vanishing point. In one sketch of a modern Canadian scene, faintly pencilled-in grid lines and a diagonal line are still visible. Banting's Spanish street scenes, while architecturally accurate, lack passion as he seemed more interested in representing an exact rendering than a scene imbued with feeling and insight. It is in his sketches of Spanish farmers and affectionate renderings of animals where one can see Banting bringing his interest in personality and its physical manifestations to play.

Banting's paintings are more conservative. His brush strokes are controlled and the bold lines of his sketches are absent, although he does take some risk with colour. Dennis Reid, the former director of Collections and Research at the Art Gallery of Ontario, views Banting as "very much under the shadow of Jackson," that his paintings are the "work of an acolyte" whose work is "part of the Jackson story."
This association continues to form a backdrop to his work. During his lifetime Banting earned only \$13.77 from his art work: royalties from the reproduction of his paintings on postcards. Today, his works do extremely well at auction. Rooftops, Quebec City, an oil on panel work, recently sold for more than $\$ 76000$. Robert Heffel, vice president of Heffel Fine Art said Banting's paintings will continue to receive attention at auction due to the Jackson association, a "hook" for potential buyers.

Banting embraced challenge both in his scientific research and in his art. In both realms his methods were methodical, determined and inspired by a love of discovery. "Scientific research," Banting said "is nothing more than the endeavour to unfold the secrets of nature. When once the law underlying natural phenomenon is understood, we are placed in a better position to govern those phenomena." ${ }^{5}$ Art, like science, was another secret landscape Banting wanted to explore.

\section{J. Lynn Fraser BA(d) MES}

Writer and amateur painter

Toronto, Ont.

\section{REFERENCES}

1. Hume SE. Frederick Banting: hero, healer, artist. Montréal (QC): XYZ Publishers; 2001.

2. Shaw MM. Frederick Banting. Don Mills (ON): Fitzhenry \& Whiteside; 1976

3. Jackson AY. The Arctic 1927. Moonbeam (ON): Penumbra Press; 1982.

4. Jackson AY. A painter's country: the autobiography of A.Y. Jackson. Toronto (ON): Clark, Irwin; 1958.

5. Jackson AY. Banting as an artist. Toronto (ON): The Ryerson Press; 1943. 